\title{
Sistem Informasi Pendataan Nilai Rapor dan Absensi Siswa pada MTs Hidayatullah Mataram Berbasis Desktop
}

\section{Information System for Data Collection on Student Reports and Attendance at MTs Hidayatullah Mataram Based on Desktop}

\author{
Baiq Candra Herawati ${ }^{1}$, Eria Raudhatul Jannah ${ }^{2}$, Lalu Zazuli Azhar Mardedi ${ }^{3}$, Khairan Marzuki ${ }^{4}$, \\ Apriani $^{5}$ \\ 1,2,3,4,5Fakultas Teknik dan Desain, Universitas Bumigora \\ candrah@universitasbumigora.ac.id ${ }^{1}, 1700330030 @$ universitasbumigora.ac.id ${ }^{2}$, \\ zazuli@stmikbumigora.ac.id ${ }^{3}$, khairan.marzuki@universitasbumigora.ac.id ${ }^{4}$, \\ apriani@universitasbumigora.ac.id ${ }^{5}$
}

Submitted: 14 Desember 2021, Revised: 19 Desember 2021, Accepted: 21 Desember 2021

\begin{abstract}
Abstrak - Sistem informasi pendataan nilai rapor dan absensi siswa berbasis desktop merupakan suatu sistem yang dapat membantu guru dan wali kelas dalam hal mendata nilai siswa dan merekap absensi siswa menjadi lebih mudah. Tujuan dari pembuatan aplikasi ini adalah untuk membangun suatu sistem informasi pendataan nilai rapor dan absensi siswa yang mempermudah pengecekan, pembuatan data nilai dan rapor, serta pembuatan laporan absensi siswa. Metode yang digunakan pada pengembangan sistem informasi ini adalah dengan metode research and development (penemuan, pengembangan dan pengujian produk). Sistem informasi pendataan nilai rapor dan absensi siswa menggunakan multiuser yang terdiri dari admin, kepala sekolah, guru dan wali kelas. Penelitian ini telah menghasilkan sebuah sistem pengolahan nilai yang membantu kerja dari para guru dan wali kelas. Dengan adanya sistem pendataan nilai dan absensi siswa secara komputerisasi, pengolah data, penyajian informasi nilai, dan pembuatan laporan absensi akan lebih cepat, serta keamanan data akan lebih terjamin karena tempat atau media penyimpanan lebih terjaga.
\end{abstract}

Kata Kunci: Sistem informasi, pendataan, nilai, rapor, absensi.

\begin{abstract}
The desktop-based student attendance and report card data collection information system is a system that can help teachers and homeroom teachers in terms of recording student grades and recapitulating student attendance more easily. The purpose of making this application is to build an information system for collecting report cards and student attendance that makes it easier to check, create grades and report cards, and make student attendance reports. The method used in the development of this information system is the research and development method (discovery, product development and testing). The information system for data collection of report cards and student attendance uses a multiuser consisting of admin, principal, teacher and homeroom teacher. This research has produced a value processing system that helps the work of teachers and homeroom teachers. With the existence of a computerized data collection system for grades and student attendance, data processing, presenting value information, and making attendance reports will be faster, and data security will be more guaranteed because the storage space or media is more secure.
\end{abstract}

Keywords: Information systems, data collection, values, report cards, attendance.

Jurnal Bumigora Information Technology (BITe)

Vol.3, No.2, Desember 2021, pp. 185-198

ISSN: 2685-4066

DOI: $10.30812 /$ bite.v3i2.1573 


\section{Pendahuluan}

Seiring dengan pesatnya perkembangan teknologi informasi, teknologi telah menjadi bagian yang penting dalam kehidupan manusia [1]. Teknologi informasi saat ini telah banyak diterapkan di berbagai instansi, baik pemerintah maupun swasta. Hal ini terjadi karena keberadaannya sangat berguna untuk memudahkan pekerjaan manusia. Dengan adanya teknologi informasi, suatu pekerjaan dapat diselesaikan dengan lebih efektif dan efisien [2]. Salah satu instansi yang terkena dampak perkembangan teknologi informasi adalah sekolah [3].

Nilai rapor sampai saat ini masih dipercaya sebagai salah satu tolak ukur keberhasilan siswa menempuh pendidikan di sekolah. Nilai rapor merupakan kumpulan nilai akhir dari semua mata pelajaran yang ditempuh siswa pada suatu semester tahun ajaran tertentu. Untuk menghasilkan nilai rapor, wali kelas siswa membutuhkan integrasi data dari semua guru pengampu mata pelajaran. Proses pengolahan nilai rapor seringkali membutuhkan tenaga dan waktu yang tidak sedikit, terutama jika proses tersebut dilakukan secara manual [4].

Hampir setiap lembaga pendidikan memiliki sistem penilaian yang tidak jauh berbeda [5]. MTS Hidayatullah merupakan instansi pendidikan yang ada di Kota Mataram Nusa Tenggara Barat (NTB), yang masih menerapkan sistem manual untuk pendataan nilai siswa dan pendokumentasian yang dicatat dan diarsipkan. Penggunaan komputer dalam pembuatan form penilaian siswa dan absensi pada MTS Hidayatullah Mataram hanya menggunakan Microsoft Office Word dan Microsoft Office Excel saja. Sehingga pengolahan data penilaian siswa dan absensi masih dilakukan secara manual, untuk itu dibutuhkan ketelitian yang lebih dan waktu yang banyak untuk proses pembuatan dan penyerahan laporan, dan absensi tersebut juga direkap secara manual, dilakukan oleh guru wali kelas. Manual berarti guru menulis data absensi siswa pada lembar absensi atau buku jurnal. Proses pengolahan data absensi siswa kemudian dihitung secara manual satu per satu tanpa menggunakan program pengolah data.

MTS Hidayatullah saat ini dalam melakukan pendataan nilai rapor dan absensi siswa masih berupa arsip - arsip data yang disimpan secara manual menggunakan aplikasi microsoft office excel kemudian dicetak dalam bentuk berkas-berkas. Dengan jumlah siswa yang banyak tentunya akan menyulitkan dalam pencarian data nilai siswa dan perekapan absensi untuk masuk ke dalam rapor. Oleh karena itu dibutuhkan sistem informasi yang dapat membantu dalam penyimpanan dan pendataan data nilai rapor dan absensi siswa pada MTS Hidayatullah.

\section{Metode Penelitian}

Dalam melakukan suatu penelitian, diperlukan suatu metode untuk menjadi panduan dasar dalam melakukan penelitian. Pada penelitian ini metode yang digunakan adalah metode waterfall. Metode waterfall merupakan metode pengembangan perangakat lunak yang sistematik dan sekuensial yang mulai pada tingkat dan kemajuan system sampai pada analisis, desain, kode (implementasi), test (pengujian) dan pemeliharaan.

\subsection{Metodologi Pengembangan Sistem}

Metode yang digunakan pada pengembangan sistem informasi ini adalah dengan metode Research and Development (penemuan, pengembangan dan pengujian produk). Penelitian ini menggunakan model Waterfall dalam mengembangkan perangkat lunak penelitian. Model Waterfall dapat didefinisikan sebagai proses pengembangan perangkat lunak yang umum digunakan dalam proyek-proyek perangkat lunak. Model ini merupakan model sekuensial dimana aktivitas selanjutnya dimulai ketika kegiatan satu set sebelumnya telah selesai. Model ini disebut Waterfall karena prosesnya mengalir secara sistematis dari tahap satu ke tahap berikutnya. Tahapan-tahapan yang termasuk dalam model Waterfall adalah analisis, desain, implementasi, dan pengujian [4]. Tahapan penelitian dalam model Waterfall dapat ditunjukkan pada Gambar 1. 


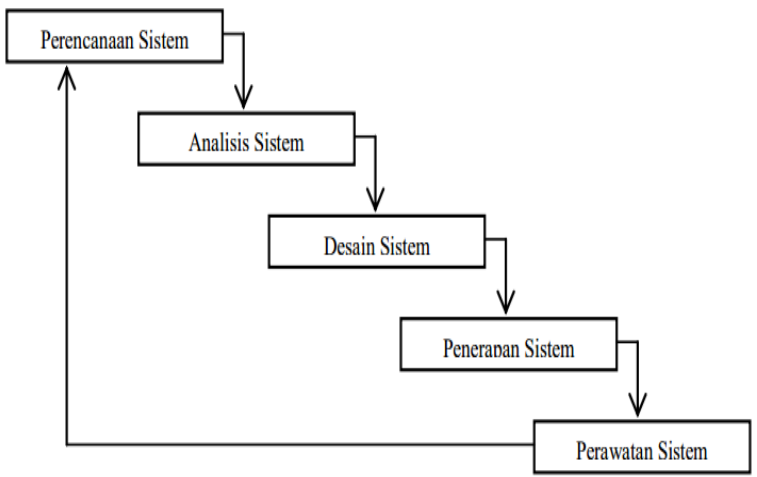

Gambar 1. Tahapan penelitian dalam model waterfal

\subsection{Analisis Permasalahan}

Tahap Analisis kebutuhan digunakan untuk menentukan output atau keluaran yang dihasilkan oleh sistem berdasarkan kebutuhan perangkat lunak (Software), kebutuhan perangkat keras (Hardware) kebutuhan sumber daya manusia.

\subsection{Desain Sistem}

Dari Hasil Penelitian yang telah penulis lakukan, penulis menemukan bahwa MTS Hidayatullah tidak memiliki sistem yang dapat memudahkan penginputan data dan pembuatan rapor siswa pada sekolah. Sistem yang digunakan masih bersifat manual dengan menggunakan Microsoft Excel untuk melakukan penginputan data dan pembuatan rapor sehingga data tidak efektif. Berikut diagram proses pendataan dan pembuatan rapor yang dilakukan saat ini ditunjukkan pada Gambar 2.

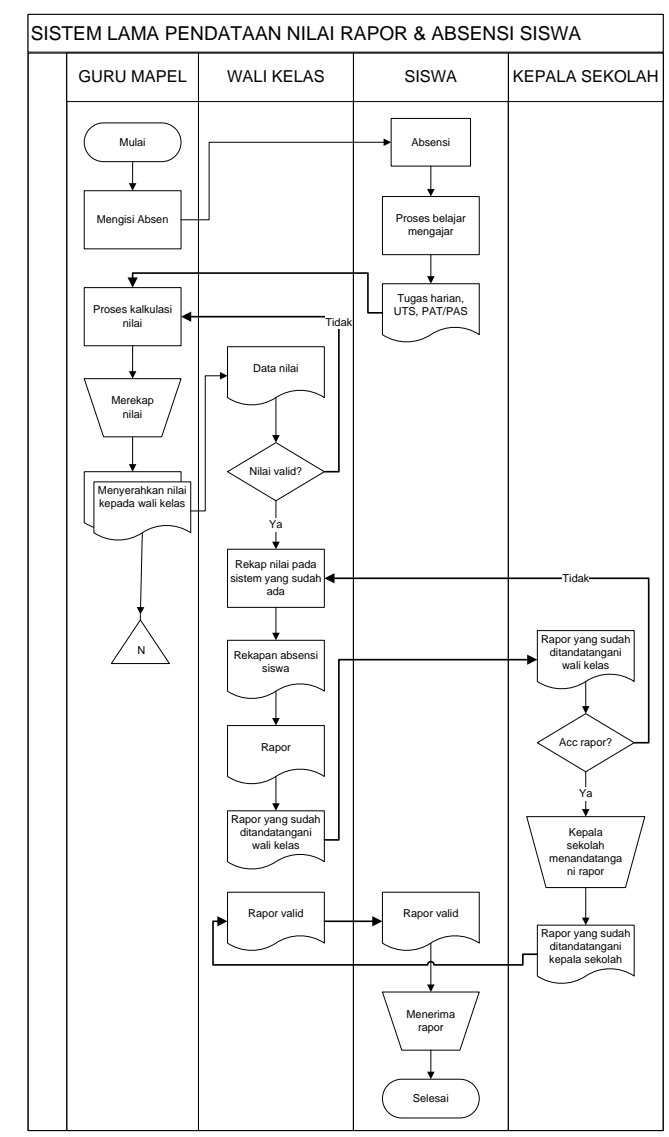

Gambar 2. Desain sistem lama pendataan nilai rapor

https://journal.universitasbumigora.ac.id/index.php/bite

ISSN: 2685-4066 


\subsection{Relasi Database}

Adapun rancangan database [6] secara keseluruhan beserta relasinya dapat dilihat pada Gambar 3.

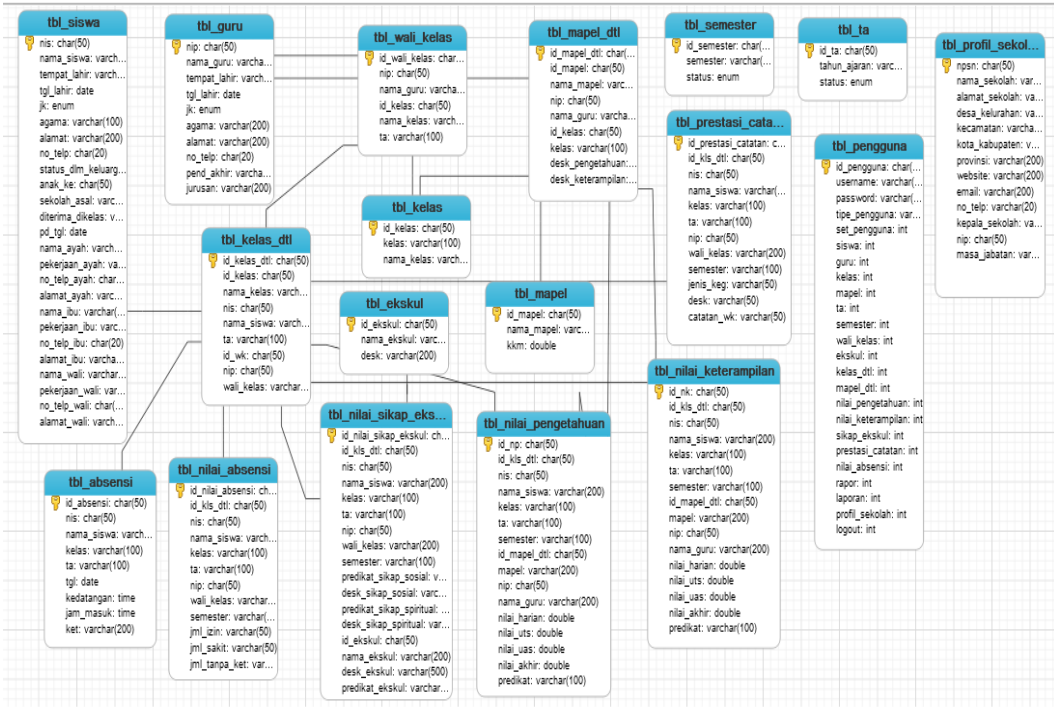

Gambar 3. Relasi database

\subsection{Model Entity Relationship Diagram (ERD)}

Squence ERD digunakan untuk membangun basis data untuk menggambarkan relasi atau hubungan dari dua file atau lebih, ERD terdiri dari dua komponen utama yaitu entitas dan relasi. Kedua komponen tersebut dideskripsikan lebih jauh melalui atribut - atribut atau property [7]. Berikut adalah relasi dari tabel yang akan digunakan ditunjukkan pada Gambar 4.

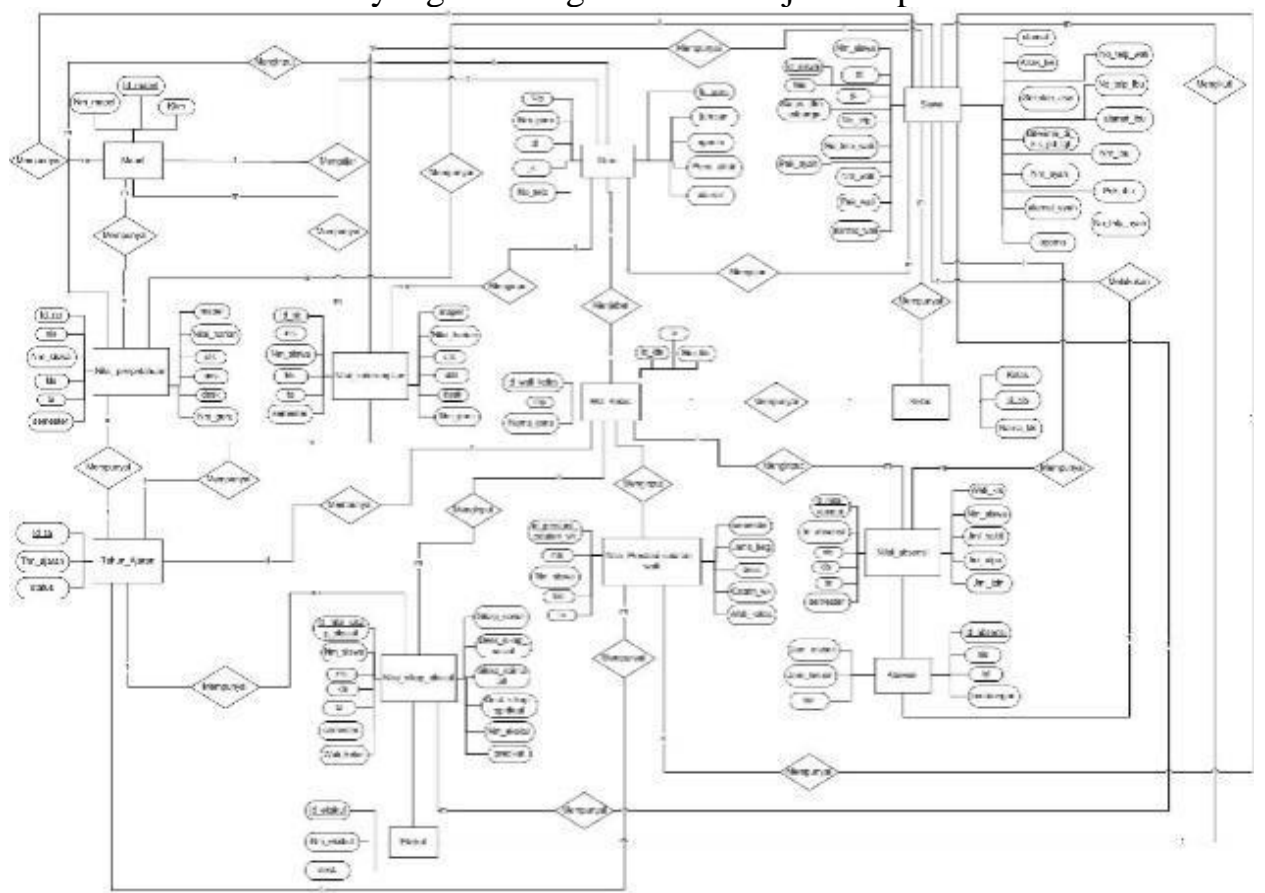

Gambar 4. Entity relationship diagram

https://journal.universitasbumigora.ac.id/index.php/bite

ISSN: 2685-4066 


\subsection{Data Flow Diagram (DFD)}

DFD digunakan untuk menggambarkan suatu sistem yang telah ada atau sistem baru yang akan digambarkan secara logika tanpa mempertimbangkan lingkungan fisik dimana data itu mengalir [8][9][10].

\subsubsection{Diagram Konteks (Level 0)}

Digaram Konteks adalah arus data yang berfungsi untuk menggambarkan keterkaitan aliran-aliran data antara sistem dengan bagian-bagaian luar [8]. Berikut adalah Diagram Konteks dari sistem informasi pendataan nilai rapor dan absensi siswa pada MTS Hidayatullah Mataram ditunjukkan pada Gambar 5.

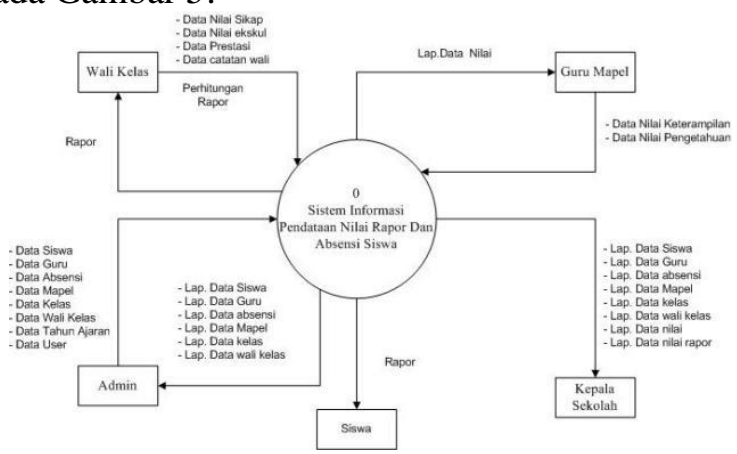

Gambar 5. Diagram Konteks (Level 0)

\subsection{Diagram Alir Data (Level 1)}

Diagram arus data level 1 merupakan diagram yang yang berada di antara diagram arus data level 0 dan diagram arus data level 2 yang merupakan penjabaran dari diagaram arus data level 0. Diagram ini dapat ditunjukkan pada Gambar 6.

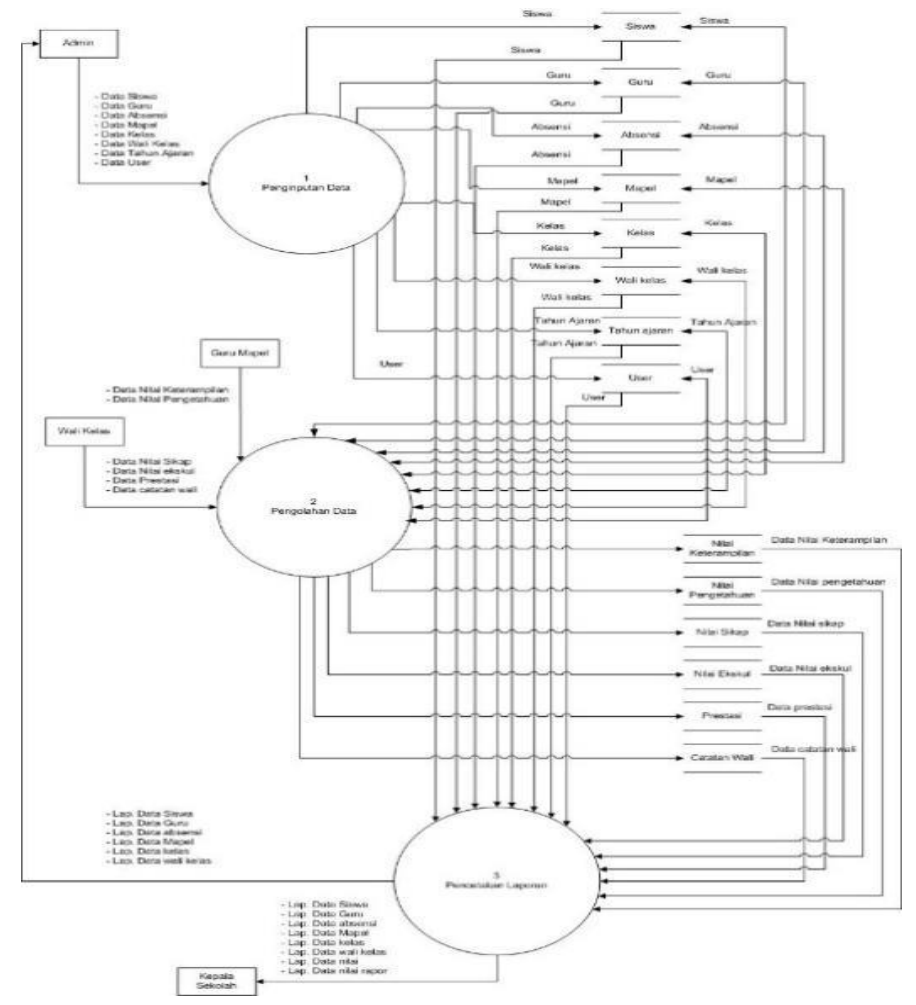

Gambar 6.Diagram Diagram Alir Data (Level 1)

https://journal.universitasbumigora.ac.id/index.php/bite

ISSN: 2685-4066 
2.6. 3 Diagram Alir Data DFD level 2 (Proses Input 1.1)

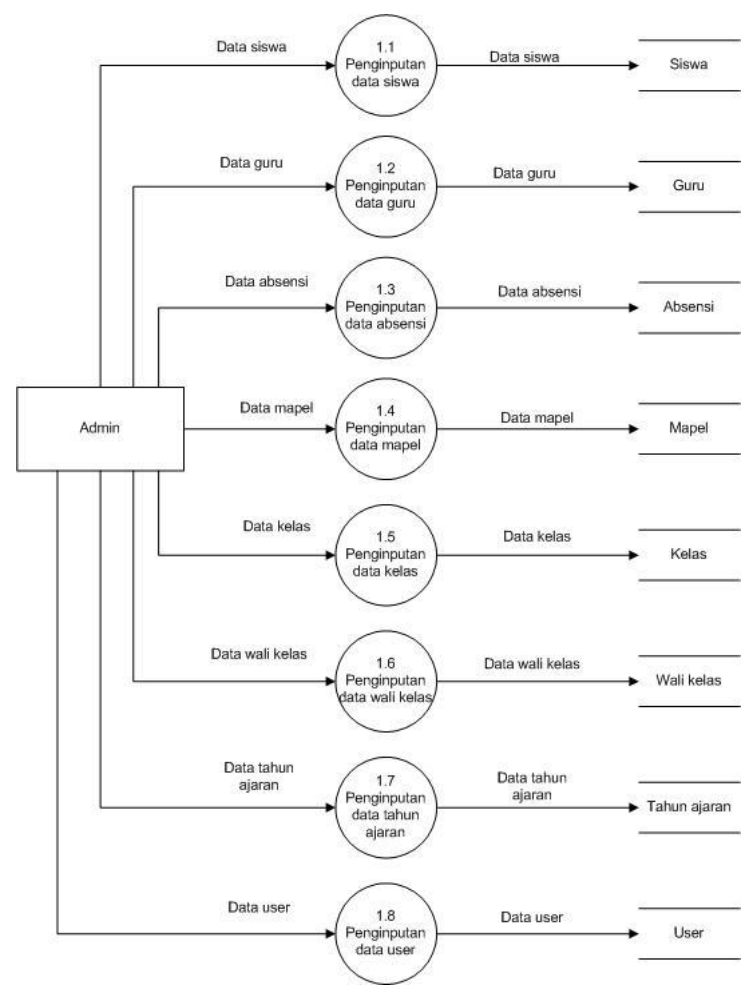

Gambar 7. Diagram Alir Data DFD level 2 (Proses Input 1.1)

2.6. 4 Diagram Alir Data DFD Level 2 (Proses Input 1.2)

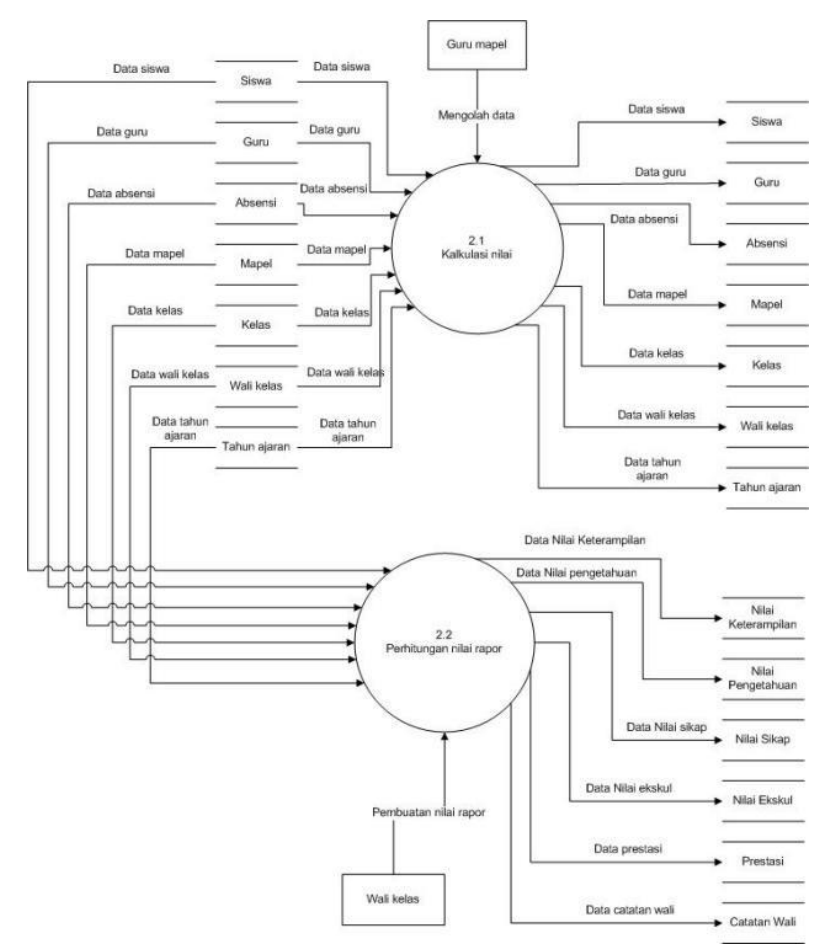

Gambar 8. Diagram Alir Data DFD Level 2 (Proses Input 1.2)

https://journal.universitasbumigora.ac.id/index.php/bite ISSN: 2685-4066 


\subsection{Diagram Alir Data DFD level 2 (Proses Output Data 3)}

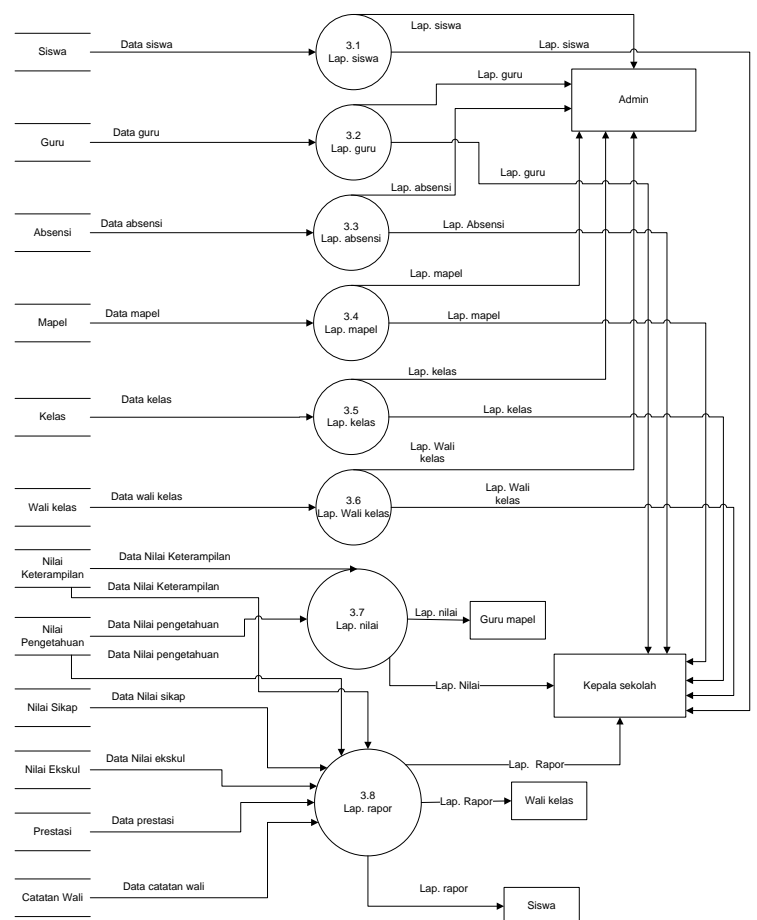

Gambar 9. Diagram Alir Data DFD level 2 (Proses Output Data 3)

Berikut adalah Squence Diagram menambah item ke menu favorit

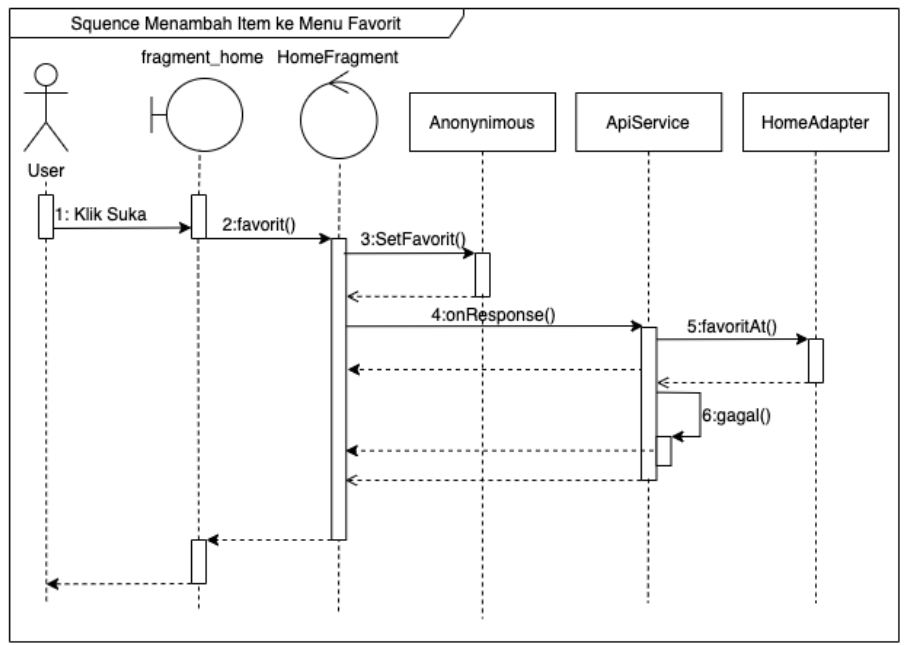

Gambar 5.Sequance Diagram Menambah Item pada Menu Favorite

\section{Hasil dan Pembahasan}

Dalam bab ini peneliti membahas hasil-hasil pengolahan data yang meliputi penjelasan program. Dengan mengacu pada metodologi penelitian yang terdapat pada bab sebelumnya maka diperoleh hasil dan pembahasan untuk suatu program Sistem Informasi Pendataan Nilai Rapor Dan Absensi Siswa Pada MTS Hidayatullah Mataram. Pada tahap pembahasan ini akan dilakukan uji coba untuk mengetahui apakah sistem dapat berfungsi seperti yang di harapkan selain itu untuk mengetahui efektivitas dan efesiensinya sistem yang dibuat melalui kesalahan yang muncul serta manfaat yang di peroleh. Maka berikut hasil dan pembahasan dari perancangan program.

https://journal.universitasbumigora.ac.id/index.php/bite ISSN: 2685-4066 


\subsection{Tampilan halaman}

\subsubsection{Form Pengaturan Pengguna}

Form pengaturan pengguna digunakan untuk menginputkan dan menampilkan data pengguna yang terdaftar pada aplikasi. Pengguna pada aplikasi ini terdiri dari 4 jenis yaitu, admin, guru mata pelajaran, wali kelas, dan kepala sekolah. Admin memiliki hak akses bisa mengakses semua data pada aplikasi. Guru mata pelajaran hanya memiliki hak akses input nilai sesuai dengan kelas dan mata pelajaran yang diajarkan. Wali kelas hanya memiliki hak akses untuk kelas yang diwalikan. Dan kepala sekolah hanya memiliki hak akses untuk melihat laporan.

\subsubsection{Form Login}

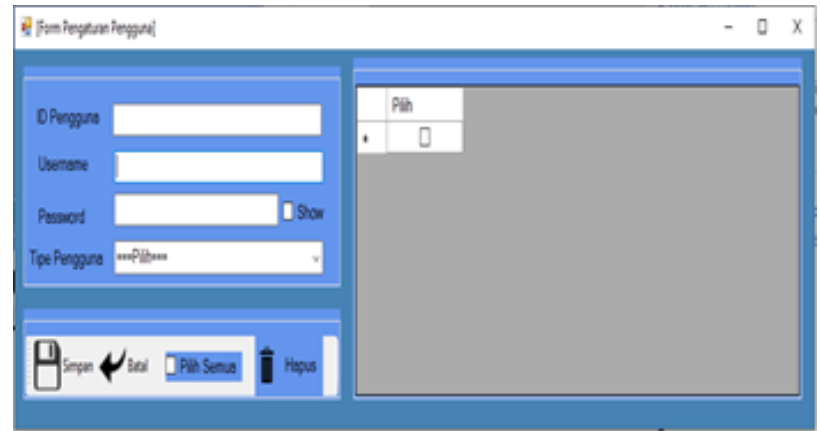

Form login merupakan form yang digunakan untuk masuk ke aplikasi tersebut. Sebelum masuk ke aplikasi maka user diharuskan untuk melakukan login terlebih dahulu dengan menggunakan username dan password yang sudah diberikan oleh admin.

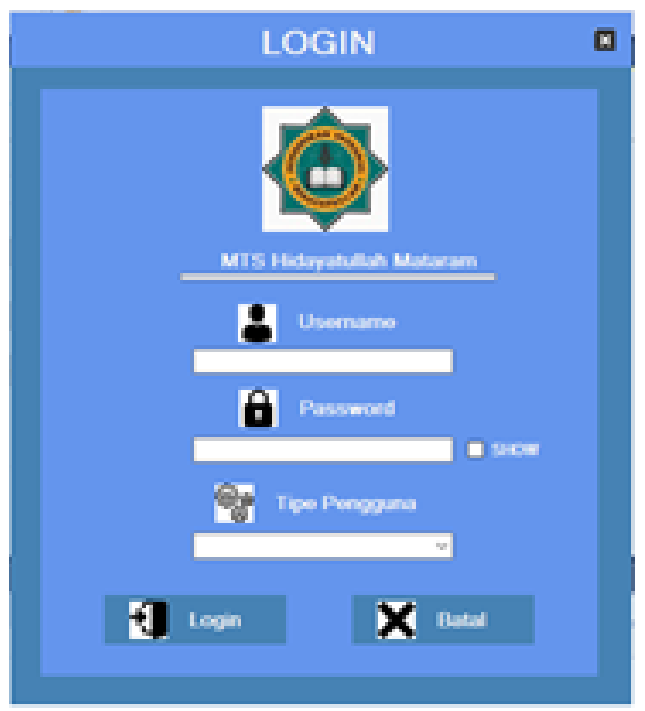

Gambar 11.Form Login

\subsubsection{Menu Utama}

Menu utama adalah menu yang pertama kali terbuka setelah user melakukan login ke sistem. Pada menu utama terdapat beberapa menu. Adapun menu yang terdapat di menu utama adalah setting pengguna, data master, data master detail, absensi, perhitungan nilai, rapor, laporan, profil sekolah, dan informasi. 


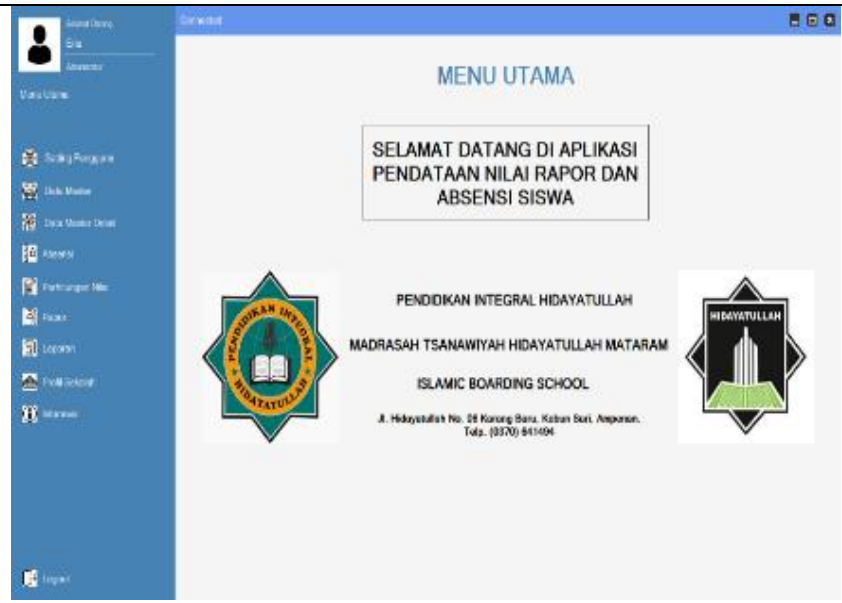

Gambar 12. Menu utama

\subsubsection{Data master}

Pada data master terdapat beberapa menu. Adapun menu yang terdapat di data master adalah data siswa, data guru, data kelas, data mata pelajaran, data tahun ajaran, data wali kelas, data ekstrakulikuler. Data master diinputkan oleh orang yang bertindak sebagai admin pada aplikasi tersebut.

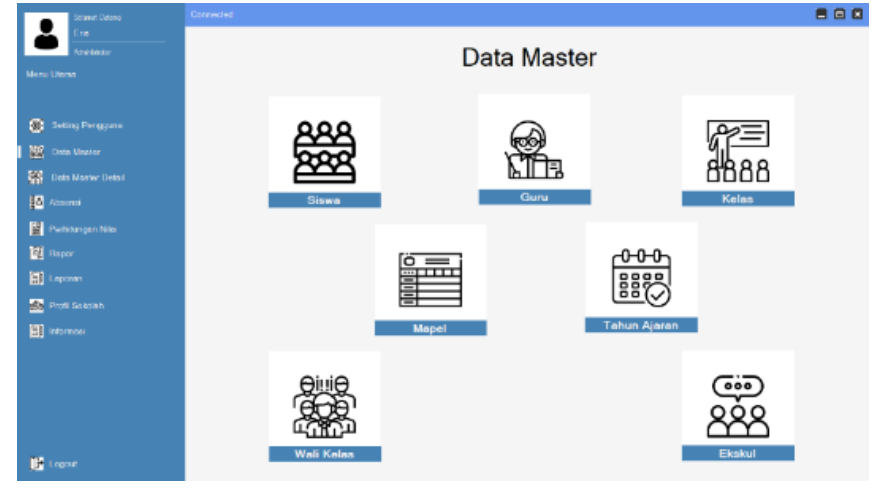

\subsubsection{Form Data Siswa}

Gambar 13.Data master

Form data siswa digunakan untuk menampilkan dan menginputkan data siswa.

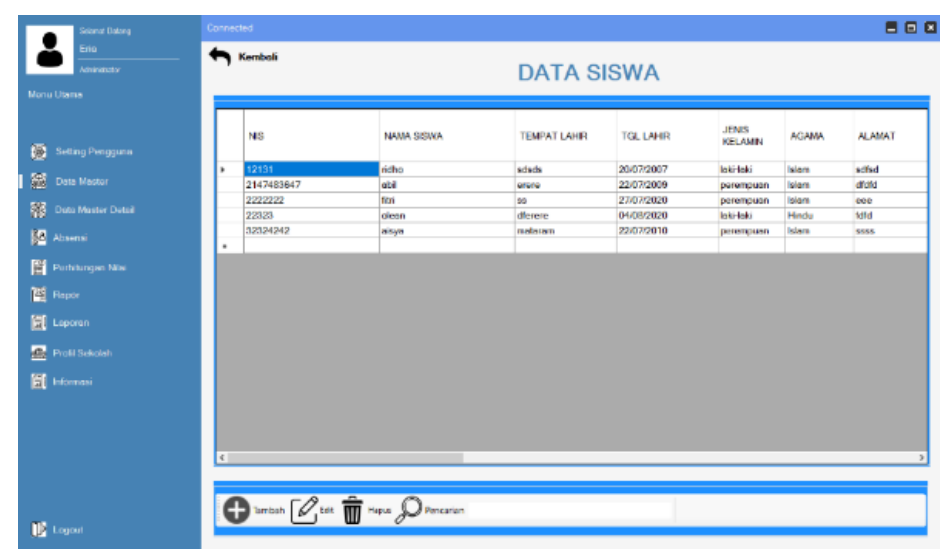

Gambar 14.Form Data Siswa 


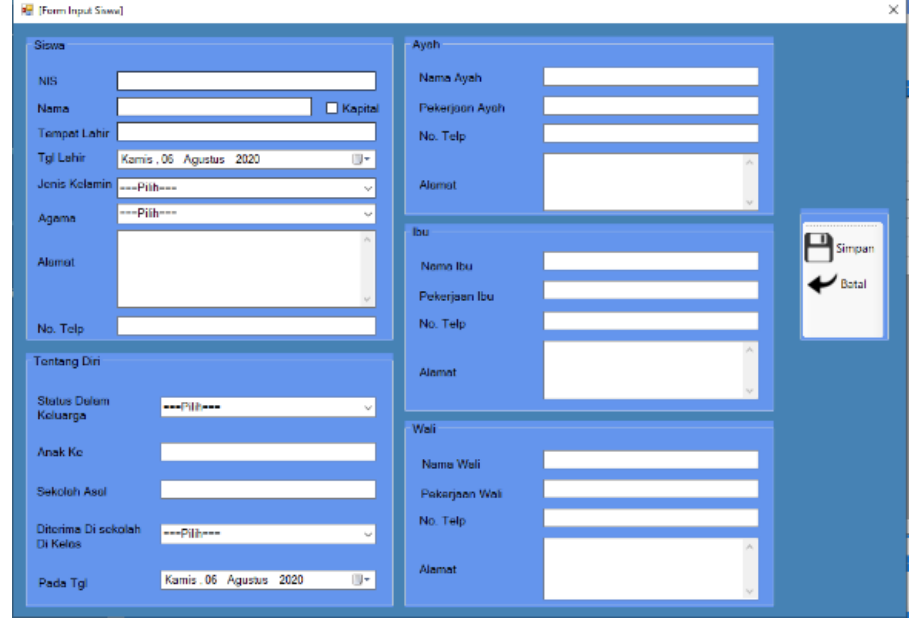

Gambar 15. Input data siswa

\subsubsection{Data mata Pelajaran}

Form data mata pelajaran detail digunakan untuk menampilkan dan menginputkan data mata pelajaran detail.
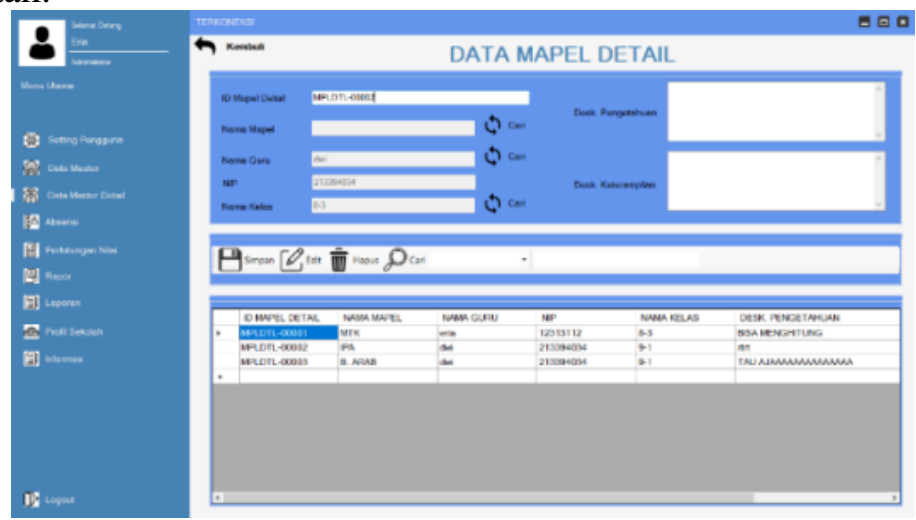

Gambar 16. Data mata pelajaran

\subsubsection{Absensi}

Form absensi digunakan untuk melakukan absensi bagi siswa.

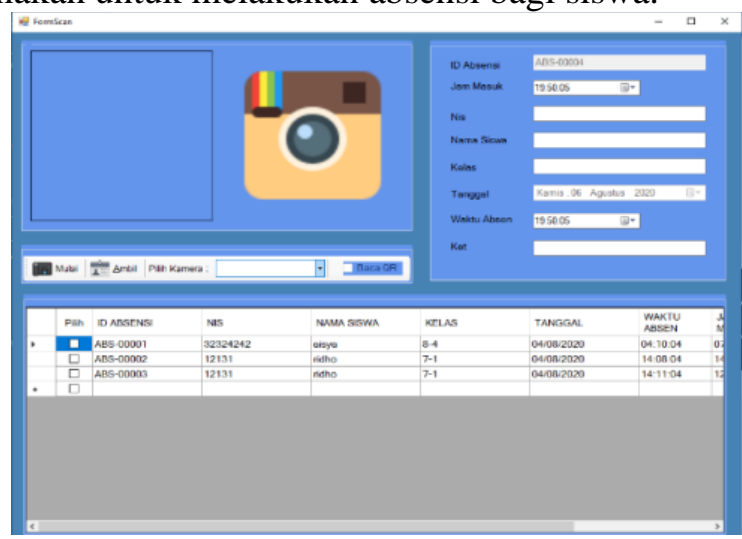

Gambar 17. Absensi

\subsubsection{Data Perhitungan Nilai}

Pada perhitungan nilai terdapat beberapa menu. Adapun menu yang terdapat pada perhitungan nilai adalah nilai pengetahuan, nilai keterampilan, nilai sikap dan ekskul, prestasi dan catatan, nilai absensi, dan laporan nilai. 


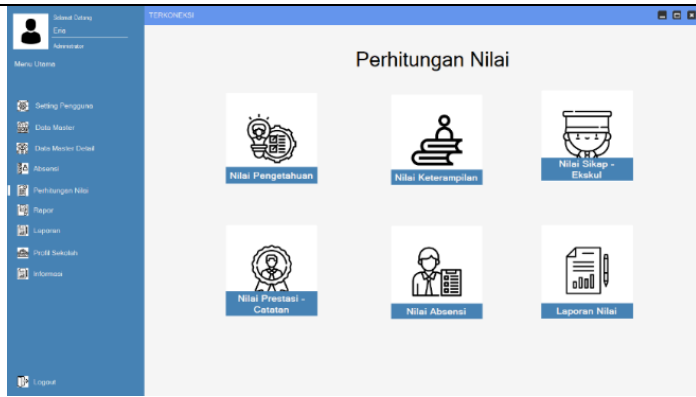

\subsubsection{Form Data Profil Sekolah}

Gambar 18.Data perhitunga nilai

Menu Form data profil sekolah digunakan untuk menampilkan dan menginputkan data profil sekolah.

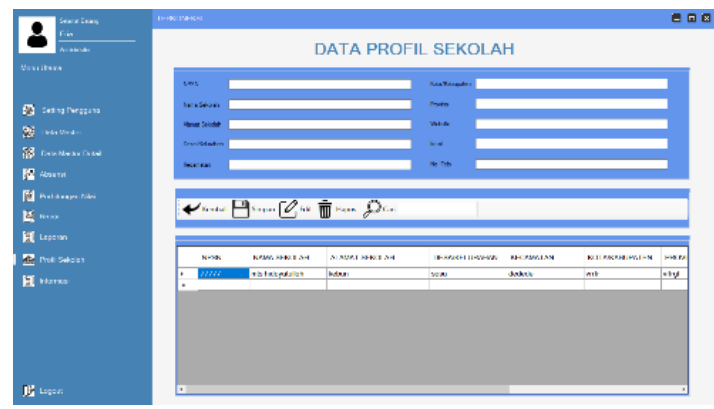

\subsection{Pengujian Sistem}

Gambar 19.Form Data profil Sekolah

Pengujian sistem merupakan tahap selanjutnya setelah program aplikasih perangkat lunak sudah selesai dalam pembuatan.

\subsubsection{Pengujian Alpha}

Tabel 1. Pengujian Alpha

\begin{tabular}{|c|c|c|c|}
\hline No & Pengujian & Keterangan & Hasil \\
\hline 1 & Setting Pengguna & $\begin{array}{l}\text { [ ok ] Diterima } \\
{\left[\begin{array}{c}\text { ] Ditolak }\end{array}\right.}\end{array}$ & $\begin{array}{l}\text { Tombol setting } \\
\text { pengguna berfungsi } \\
\text { dengan baik }\end{array}$ \\
\hline 1.1 & Input username & $\begin{array}{l}\text { [ ok ] Diterima } \\
\text { [ ] Ditolak }\end{array}$ & $\begin{array}{l}\text { Teks username } \\
\text { dapat diinput }\end{array}$ \\
\hline 1.2 & Input Password & $\begin{array}{l}\text { [ ok ] Diterima } \\
\text { [ ] Ditolak }\end{array}$ & $\begin{array}{l}\text { Teks Password } \\
\text { dapat diinput }\end{array}$ \\
\hline 1.3 & Pilih Tipe Pengguna & $\begin{array}{l}\text { [ ok ] Diterima } \\
\text { [ ] Ditolak }\end{array}$ & $\begin{array}{l}\text { Tpe Pengguna } \\
\text { berhasil dipilih }\end{array}$ \\
\hline 1.4 & Tombol Login & $\begin{array}{l}\text { [ ok ] Diterima } \\
{\left[\begin{array}{c}\text { ] Ditolak }\end{array}\right.}\end{array}$ & $\begin{array}{l}\text { Tombol Login } \\
\text { berfungsi dengan } \\
\text { baik }\end{array}$ \\
\hline 2 & Login & $\begin{array}{l}\text { [ ok ] Diterima } \\
{[\quad] \text { Ditolak }}\end{array}$ & $\begin{array}{l}\text { Tombol Login } \\
\text { berfungsi dengan } \\
\text { baik }\end{array}$ \\
\hline 2.1 & Input username & $\begin{array}{l}\text { [ ok ] Diterima } \\
\text { [ ] Ditolak }\end{array}$ & $\begin{array}{l}\text { Teks username } \\
\text { dapat diinput }\end{array}$ \\
\hline 2.2 & Input Password & $\begin{array}{l}\text { [ ok ] Diterima } \\
\text { [ ] Ditolak }\end{array}$ & $\begin{array}{l}\text { Teks Password } \\
\text { dapat diinput }\end{array}$ \\
\hline
\end{tabular}

https://journal.universitasbumigora.ac.id/index.php/bite ISSN: 2685-4066 


\begin{tabular}{|c|c|c|c|}
\hline No & Pengujian & Keterangan & Hasil \\
\hline 2.3 & Tombol Login & $\begin{array}{l}\text { [ ok ] Diterima } \\
{[\quad] \text { Ditolak }}\end{array}$ & $\begin{array}{l}\text { Tombol Login } \\
\text { berfungsi dengan } \\
\text { baik }\end{array}$ \\
\hline 3 & $\begin{array}{l}\text { Halaman Data } \\
\text { Master }\end{array}$ & $\begin{array}{l}\text { [ ok ] Diterima } \\
{[\quad] \text { Ditolak }}\end{array}$ & $\begin{array}{l}\text { Halaman Data } \\
\text { Master dapat diakses } \\
\text { dengan baik dan } \\
\text { benar }\end{array}$ \\
\hline 3.1 & Input Data Siswa & $\begin{array}{l}\text { [ ok ] Diterima } \\
{[\quad] \text { Ditolak }}\end{array}$ & $\begin{array}{l}\text { Data Siswa dapat } \\
\text { diinput }\end{array}$ \\
\hline 3.2 & Input Data Guru & $\begin{array}{l}\text { [ ok ] Diterima } \\
{[\quad] \text { Ditolak }}\end{array}$ & $\begin{array}{l}\text { Data Guru dapat } \\
\text { diinput }\end{array}$ \\
\hline 3.3 & Input Data Kelas & $\begin{array}{l}\text { [ ok ] Diterima } \\
\text { [ ] Ditolak }\end{array}$ & $\begin{array}{l}\text { Data Kelas dapat } \\
\text { diinput }\end{array}$ \\
\hline
\end{tabular}

\subsubsection{Pengujian Beta}

Pengujian Beta merupakan pengujian tahap kedua dari pengujian perangkat lunak dimana pada pengujian beta diuji secara langsung dengan membuat kuesioner mengenai kepuasan user. Adapun hasil uji coba aplikasi dapat dilihat pada table 2 berikut:

Tabel 2. Pengujian Beta

\begin{tabular}{|c|c|c|c|c|c|}
\hline No & Pertanyaan & TS & CS & $\mathbf{S}$ & SS \\
\hline 1 & $\begin{array}{l}\text { Apakah aplikasi ini } \\
\text { memiliki tampilan } \\
\text { yang menarik? }\end{array}$ & & & 1 & \\
\hline 2 & $\begin{array}{l}\text { Apakah aplikasi ini } \\
\text { mudah digunakan? }\end{array}$ & & & & 1 \\
\hline 3 & $\begin{array}{l}\text { Dengan dibangunya } \\
\text { aplikasi ini, apakah } \\
\text { dapat mempercepat } \\
\text { kinerja guru dan wali } \\
\text { kelas dalam melakukan } \\
\text { proses pendataan nilai } \\
\text { dan rapor? }\end{array}$ & & & & 1 \\
\hline 4 & $\begin{array}{l}\text { Apakah ada hambatan } \\
\text { dalam menggunakan } \\
\text { aplikasi ini? }\end{array}$ & 1 & & & \\
\hline 5 & $\begin{array}{l}\text { Apakah aplikasi sudah } \\
\text { sesuai dengan harapan } \\
\text { dan kebutuhan? }\end{array}$ & & & 1 & \\
\hline
\end{tabular}

\section{Kesimpulan}

Dari penelitian yang dilakukan dapat ditarik beberapa kesimpulan yaitu sistem informasi pendataan nilai rapor membantu guru dan wali kelas dalam hal mendata nilai siswa menjadi lebih mudah. Data absensi siswa sudah dapat tersimpan dalam database sehingga mempermudah dalam membuat laporan daftar kehadiran siswa. Dengan adanya sistem pendataan nilai secara komputerisasi pengolah data, penyajian informasi nilai akan lebih cepat, serta keamanan data akan lebih terjamin karena tempat atau media penyimpanan lebih terjaga. 


\section{Ucapan Terima Kasih}

Penulis ingin mengucapkan terima kasih kepada pihak - pihak yang telah banyak membantu dalam penyelesaian penelitian teruatama pihak MTs Hidayatullah Mataram, dan LPPM Universitas Bumigora.

\section{Referensi}

[1] E. N. Jannah and A. Z. Arifin, "Sistem informasi absensi haul berbasis web di pondok pesantren muhyiddin Surabaya," Register: Jurnal Ilmiah Teknologi Sistem Informasi, vol. 1, no. 1, pp. 47-59, 2015, doi: 10.26594/register.v1i1.405.

[2] M. Alfian and E. Retnoningsih, "Sistem Informasi Pengolahan Nilai Pada SMK PGRI 1 Tambun Selatan," vol. 3, no. 2, pp. 201-214, 2019.

[3] B. Kusuma Riasti and B. Eka Purnama, "Pembangunan Sistem Informasi Penilaian Hasil Belajar Siswa Sekolah Menengah Atas (SMA) Negeri 2 Rembang Berbasis Web," IJNSIndonesian Journal on Networking and Security, vol. 4, no. 2, p. 54, 2015.

[4] Hardiyan and Mahpud, "Hardiyan \& Mahpud, 2017," Techno Nusa Mandiri, vol. XIV, no. 1, pp. 43-48, 2017.

[5] M. Purba, "Aplikasi Pengolahan Data Nilai Siswa Pada Sekolah Dasar Negeri 152 Palembang Menggunakan Metode Waterfall," pp. 42-52, 2017.

[6] Suriyati and B. A. Ulfa, "Rancangan Desain Informasi Portal Berita Lokal ( Studi Kasus Berita Lokal dikabupaten Dompu )," Jurnal Bumigora Information Technology (BITe), vol. 1, no. 2, pp. 138-142, 2019.

[7] S. Rejeki, Utomo, "Perancangan dan Pengaplikasian Sistem Penjualan pada 'Distro Smith' Berbasis E-Commerce."

[8] A. Kadir, Pemrograman Database MySql Untuk Pemula. Yogyakarta, 2013.

[9] L. W. Wardani and A. Adil, "Sistem Informasi untuk Mengetahui Penyebab Mahasiswa Tidak Lulus Tepat Waktu Studi Kasus STMIK Bumigora Mataram," Jurnal Bumigora Information Technology (BITe), vol. 1, no. 1, pp. 60-68, 2019.

[10] R. A. G. Anwar, K. Kartarina, and M. Madani, "Sistem Informasi Antrean Pada Pusat Layanan Kesehatan Masyarakat Dengan Electronic Kartu Tanda Penduduk Menggunakan Radio Frequency Identification," Jurnal Bumigora Information Technology (BITe), vol. 3, no. 1, pp. 9-18, 2021, doi: 10.30812/bite.v3i1.1304. 
